\title{
academicJournals
}

Vol. 10(8), pp. 302-305, 30 April, 2015

DOI: $10.5897 /$ SRE2014.5792

Article Number:F1627AE52670

ISSN 1992-2248

Copyright@-2015

Scientific Research and Essays

Author(s) retain the copyright of this article

http://www.academicjournals.org/SRE

\section{Group balanced block design for comparisons among oilseed Brassicae}

\author{
A. B. Shikari, G. A. Parray, N. R. Sofi, A. Hussain, Z. A. Dar and A. M. Iqbal* \\ Mountain Research Centre for Field Crops, Khudwani, 192 102, Anantnag J\&K, Sher-e-Kashmir University of \\ Agricultural Sciences and Technology of Kashmir India. \\ Received 2 January, 2014; Accepted 9 April, 2015
}

\begin{abstract}
The brassica genus contains the most genetically diverse collection of agriculturally important plant species, including oilseed, mustard and cruciferous species. Comparisons for seed yield and its components were drawn among brown (Brassica rapa var. brown sarson), gobhi (Brassica napus) and yellow sarson (B. rapa var. trilocularis). Brown sarson was found high yielder by virtue of its high siliquae number per plant and recorded maturity duration between the two. $B$. napus entries were late and showed intermediate seed yield. Significant mean squares were noted for all the traits among and within groups.
\end{abstract}

Key words: Brassica rapa, Brassica napus, sarson, maturity, yield.

\section{INTRODUCTION}

Brassica is a genus of the Brassicaceae (Cruciferae), commonly known as the Cruciferae family and are among the oldest cultivated plants known to humans with written records dating back to ca. 1500 BC (Prakash, 1980) and archaeological evidence of its importance dating back to 5000 BC (Yan, 1990) .

The Brassicaceae, which currently includes 3709 species and 338 genera (Warwick et al., 2006), is one of the ten most economically important plant families (Rich, 1991). The genus brassica has mainly Mediterranean distribution, but it extends to Asia and Africa, including
India. Oilseed rape has been cultivated for thousands of years in Asia and the Indian subcontinent and then later in Europe.

The research carried by Morinaga (1934) revealed that brassicas consist of six species, three of them are monogenomic diploids viz Brassica nigra $(n=8)$, Brassica oleraceae $(n=9)$ and Brassica Campestris $(n=10)$ while as, three are chromosome digenomic tetraploids, Brassica carinata $(n=17)$, Brassica juncea $(n=18)$ and Brassica napus $(n=19)$, which evolved in nature through convergent allopolyploid evolution between any of the 
two diploid species. Brassica species are widely used in human diet mainly as an important source of vegetables, condiments, and edible oils (Branca and Cartea, 2011). Rapeseed-mustard seed is rich in oil and protein and contains 40 to $46 \%$ oil and 18 to $22 \%$ protein. In addition the oil content of Brassica seed meal contains about $40 \%$ protein with well-balanced amino acid (Miller et al., 1962) but lower than would be desired. The use of the related crops is cited in some ancient civilized regions such as in the Mediterranean and in Asia (Shaukat et al., 2014).

Rapeseed was the third largest source of vegetable oil in the world (after soybean and palm) and the second world source of protein, although it reached only a fifth of the soybean production. To assess and predict the possibilities and consequences of inter-specific hybridization, besides other factors it is important to know the flowering chronology and other important agromorphological traits related to seed yield across different Brassica species (Anonymous, 1999). Usually among the three ecotypes brown sarson is more adaptable to environment in Kashmir, while gobhi sarson tends to be late.

Available germplasm of yellow sarson has shown little tolerance to cold. The study was undertaken to establish the differences with respect to yield and its component attributes within and among the genotypes in three Brassica species viz., Brassica rapa var. brown sarson (or brown sarson), B. rapa var. trilocularis (or yellow sarson) and $B$. napus (gobhi sarson).

\section{MATERIALS AND METHODS}

The experimental material comprised of 10 genotypes of brown ( $B$. rapa var. brown sarson), gobhi (B. napus) and yellow sarson ( $B$. rapa var. trilocularis) each were laid in a group balanced block design with 3 replications during rabi 2008-09 at MRCFC,Khudwani, Sher-e-Kashmir University of Agricultural Sciences and Technology of Kashmir, India. The said experimental material was procured from Directorate of Rapeseed-mustard Bharartpur.

Each genotype was grown in a $5 \mathrm{~m}$ row length with three rows/plot with a crop geometry of $30 \times 10 \mathrm{~cm}$. The analysis of variance was performed following Gomez and Gomez (1983). The observations were recorded for 12 agro-morphological characters such as, plant height $(\mathrm{PH})$, days to $50 \%$ flowering (DF), days to maturity (DM), primary branches per plant (PB), secondary branches per plant $(S B)$, main raceme length $(R L)$, siliquae on main raceme (SM), total siliquae per plant (TS), siliqua length (SL), 1000seed weight (SW), seeds per siliqua (SS) and seed yield per plant (SY).

Barring DF and DM, observations for all the traits were recorded on 10 randomly selected competitive plants per entry per replication. All the recommended package and practices were adapted to raise a good crop.

\section{RESULTS AND DISCUSSION}

The perusal of the results revealed that among the three
Brassica groups viz., brown sarson, gobhi sarson and yellow sarson, significantly high average mean values over the constituent genotypes were exhibited by brown sarson group with respect to traits $\mathrm{PH}, \mathrm{RL}, \mathrm{SM}$ and TS followed through gobhi sarson to yellow sarson (Table 1). Highest average mean values for DF and DM were recorded for gobhi sarson which established that this Brassica groups tend to be late in maturity (231 DAS) under Kashmir conditions while, yellow sarson matures on an average 14 days earlier than brown sarson (205 DAS).

Since gobhi sarson usually shows delayed maturity than brown sarson, at least here by 26 days, this remains perhaps the biggest deterrent to fit elite gobhi sarson germplasm in rice-rapeseed rotation. The trait SW weight exhibits highest average mean for gobhi sarson followed by yellow sarson and brown sarson sequentially. Statistically non-significant differences were recorded for SS between gobhi and brown sarson group, however, the trait recorded highest mean (27 seeds per siliqua) over the genotypes in yellow sarson group (Sinhamahapatra et al., 2003).

This was because of the tetra-locular siliquae of the genotypes in yellow sarson compared to bi-chambered nature of most of the gobhi and all the brown sarson entries. More importantly, highest average SY was exhibited by brown sarson ( $1167 \mathrm{~kg} / \mathrm{ha})$ against other two groups those showed yield at par between them. Brown sarson out-yielded two other sarson types by virtue of significantly higher SM and TS than either of the two. Similar comparisons were made between three Brassica groups by Varshney et al. (1986) and Shikari and Sinhamahapatra (2004).

Analysis of variance revealed that highly significant variation existed among three Brassica groups for all the twelve characters (Table 2). The Brassica species recorded significant to highly significant variability within the groups for all the characters under study except SB and SL for yellow and brown sarson respectively. Also, non-significant mean squares for DF were noted within brown sarson group.

High significant mean squares were shown by three primary yield attributes that is, SS, TS and SW among and within the groups except within yellow sarson group for TS.

Since brown sarson is the only Brassica oilseed grown in Kashmir valley, the comparisons made above highlights the importance of breeding early maturing gobhi sarson types with high TS, SW and SS. Yellow sarson usually remains low yielder out of the three, though could be used in hybridization for improving SW, maturity traits and oil content.

\section{Conflict of Interest}

The authors have not declared any conflict of interest. 
Table 1. Comparison using Group Balanced Block Design among and within groups representing three Brassica species for yield and its components.

\begin{tabular}{|c|c|c|c|c|c|c|}
\hline Group/ statistic & Plant height (cm) & $\begin{array}{c}\text { Days to } 50 \% \\
\text { flowering }\end{array}$ & $\begin{array}{l}\text { Days to } \\
\text { maturity }\end{array}$ & $\begin{array}{c}\text { Number of primary } \\
\text { branches }\end{array}$ & $\begin{array}{c}\text { Number of secondary } \\
\text { branches }\end{array}$ & $\begin{array}{c}\text { Main raceme length } \\
(\mathrm{cm})\end{array}$ \\
\hline Range (Gobhi sarson) & $68.87-97.60$ & $164.67-175.00$ & $226.67-235.33$ & $3.87-5.87$ & $5.27-8.70$ & $34.47-40.87$ \\
\hline $\begin{array}{ll}\text { Range } & \text { (Yellow } \\
\text { sarson) } & \end{array}$ & $34.64-63.32$ & $136.33-158.40$ & $164.33-203.87$ & $3.10-5.21$ & $2.31-3.67$ & $17.97-35.07$ \\
\hline Range (Brown sarson) & $81.13-109.47$ & $161.33-165.67$ & $191.67-214.33$ & $3.60-6.17$ & $1.40-5.90$ & $44.53-62.40$ \\
\hline Mean (Gobhi sarson) & 84.94 & 170.67 & 231.30 & 4.66 & 6.85 & 37.91 \\
\hline Mean (Yellow sarson) & 51.97 & 151.00 & 191.30 & 4.07 & 3.02 & 27.37 \\
\hline Mean (Brown sarson) & 100.64 & 163.37 & 205.43 & 4.62 & 3.57 & 50.96 \\
\hline $\begin{array}{l}\text { Grand mean over } \\
\text { groups }\end{array}$ & 79.18 & 161.68 & 209.34 & 4.45 & 4.48 & 38.74 \\
\hline $\begin{array}{l}\text { CD (at 5\%) among } \\
\text { groups }\end{array}$ & 5.87 & 1.20 & 5.30 & 0.36 & 0.62 & 7.13 \\
\hline $\begin{array}{l}\mathrm{CD}(\text { at } 5 \%) \text { within } \\
\text { groups }\end{array}$ & 4.98 & 1.38 & 1.88 & 0.36 & 0.53 & 1.84 \\
\hline CV (\%) among groups & 7.38 & 0.74 & 2.52 & 7.98 & 13.67 & 18.30 \\
\hline CV (\%) within groups & 7.99 & 1.08 & 1.14 & 10.36 & 14.94 & 6.04 \\
\hline Group/ statistic & $\begin{array}{c}\text { Siliqua on main } \\
\text { raceme }\end{array}$ & Siliquae/plant & $\begin{array}{c}\text { Siliqua length } \\
\text { (cm) }\end{array}$ & $1000-$ seed weight $(\mathrm{g})$ & Seeds/ siliqua & $\begin{array}{c}\text { Seed yield / hectare } \\
(\mathrm{kg})\end{array}$ \\
\hline Range (Gobhi sarson) & $27.87-41.80$ & $48.88-136.82$ & $4.18-4.99$ & $3.07-4.58$ & $16.44-22.62$ & $464.76-1246.00$ \\
\hline $\begin{array}{ll}\text { Range } & \text { (Yellow } \\
\text { sarson) } & \end{array}$ & $16.67-31.67$ & $40.43-67.58$ & $3.11-4.06$ & $3.27-4.20$ & $21.30-30.93$ & $494.56-868.05$ \\
\hline Range (Brown sarson) & $42.73-60.67$ & $99.80-225.50$ & $4.78-5.49$ & $1.97-2.93$ & $13.43-20.68$ & $838.89-1475.00$ \\
\hline Mean (Gobhi sarson) & 34.02 & 97.90 & 4.60 & 3.79 & 18.75 & 753.02 \\
\hline Mean (Yellow sarson) & 24.40 & 55.63 & 3.58 & 3.59 & 27.02 & 644.73 \\
\hline Mean (Brown sarson) & 51.12 & 127.49 & 5.22 & 2.32 & 17.24 & 1167.81 \\
\hline $\begin{array}{l}\text { Grand mean over } \\
\text { groups }\end{array}$ & 36.51 & 93.67 & 4.46 & 3.23 & 21.00 & 855.18 \\
\hline $\begin{array}{l}\text { CD (at 5\%) among } \\
\text { groups }\end{array}$ & 2.08 & 5.44 & 0.76 & 0.05 & 2.33 & 125.32 \\
\hline $\begin{array}{l}\mathrm{CD}(\text { at } 5 \%) \text { within } \\
\text { groups }\end{array}$ & 2.36 & 8.22 & 0.21 & 0.07 & 0.92 & 59.90 \\
\hline CV (\%) among groups & 5.67 & 5.78 & 16.97 & 1.50 & 11.04 & 14.58 \\
\hline
\end{tabular}


Table 2. Mean squares among and within different Brassica species grown in group balanced block design.

\begin{tabular}{|c|c|c|c|c|c|c|c|}
\hline \multirow[b]{2}{*}{ Source of variation } & \multirow[b]{2}{*}{ df } & \multicolumn{6}{|c|}{ Mean sum of squares } \\
\hline & & Plant height (cm) & $\begin{array}{l}\text { Days to } 50 \% \\
\text { flowering }\end{array}$ & $\begin{array}{l}\text { Days to } \\
\text { maturity }\end{array}$ & $\begin{array}{l}\text { Number of primary } \\
\text { branches }\end{array}$ & $\begin{array}{c}\text { Number of } \\
\text { secondary } \\
\text { branches }\end{array}$ & Main raceme length $(\mathrm{cm})$ \\
\hline Replications & 2 & 46.40 & 0.18 & 20.35 & 0.35 & 0.39 & 62.37 \\
\hline Groups & 2 & $18515.72^{* *}$ & $2963.94^{* *}$ & $12344.18^{* *}$ & $3.20^{* *}$ & $128.57^{\star \star}$ & $4188.52^{* *}$ \\
\hline Error (a) & 4 & 34.10 & 1.42 & 27.77 & 0.13 & 0.37 & 50.29 \\
\hline Gobhi sarson & 9 & $194.03^{\star \star}$ & $30.74^{\star \star}$ & $20.26^{\star *}$ & $1.03^{* *}$ & $5.13^{* *}$ & $20.73^{* *}$ \\
\hline Yellow sarson & 9 & $267.38^{* *}$ & $194.58^{* *}$ & $484.73^{* *}$ & $1.34^{\star \star}$ & 0.59 & $77.86^{\star *}$ \\
\hline Brown sarson & 9 & $232.60^{* *}$ & 5.96 & $215.93^{* *}$ & $1.74^{\star \star}$ & $5.12^{* *}$ & $90.41^{* *}$ \\
\hline Error (b) & 54 & 40.06 & 3.06 & 5.67 & 0.21 & 0.45 & 5.48 \\
\hline \multirow[t]{2}{*}{ Source of variation } & df & $\begin{array}{l}\text { Siliqua on main } \\
\text { raceme }\end{array}$ & Siliquae/plant & $\begin{array}{c}\text { Siliqua length } \\
(\mathrm{cm})\end{array}$ & $\begin{array}{c}\text { 1000- seed weight } \\
(\mathrm{g})\end{array}$ & Seeds/ siliqua & Seed yield / hectare $(\mathrm{kg})$ \\
\hline & & 7.99 & 35.87 & 0.58 & 0.01 & 4.34 & 6374.13 \\
\hline Groups & 2 & $5495.88^{* *}$ & $39122.89^{* *}$ & $20.62^{* *}$ & $18.92^{* *}$ & $831.94^{* *}$ & $2286927.22^{* *}$ \\
\hline Error (a) & 4 & 4.29 & 29.34 & 0.57 & 0.01 & 5.38 & 15553.82 \\
\hline Gobhi sarson & 9 & $66.15^{* *}$ & $1881.00^{* *}$ & $0.17^{*}$ & $0.91^{* *}$ & $13.40^{* *}$ & $182184.68^{* *}$ \\
\hline Yellow sarson & 9 & $66.95^{\star *}$ & 213.54 & $0.24^{* *}$ & $0.20^{* \star}$ & $25.95^{\star \star}$ & $52209.25^{* *}$ \\
\hline Brown sarson & 9 & $89.49^{* *}$ & $3955.99^{* *}$ & 0.14 & $0.34^{\star *}$ & $22.20^{* *}$ & $145937.57^{* *}$ \\
\hline Error (b) & 54 & 8.99 & 108.82 & 0.07 & 0.01 & 1.36 & 5784.54 \\
\hline
\end{tabular}

** and * indicates $\mathrm{P}(<0.01)$ and $\mathrm{P}(<0.05)$ respectively.

\section{REFERENCES}

Anonymous (1999). The Biology of Brassica rapa (L): Regulatory Directive, Directorate of Health and Productive Division, Canada Food Inspection Agency, P. 7.

Branca F, Cartea E (2011). Wild Crop Relatives: Genomic and Breeding Resources, Oilseeds. Springer-Verlag Berlin Heidelberg C. Kole (ed.), pp. 17-36.

Gomez KA, Gomez AA (1983). Statistical procedures for Agricultural Research, $2^{\text {nd }}$ edn., John Wiley and Sons, New
York. York.

Prakash S, Hinnata K (1980). Taxanomy, cytogenetics and crop brassicas. Opera. Bot. 55:1-57.
Rich TCG (1991). Crucifers of Great Britain and Ireland. Botanical Society of the British Isles, London. P. 336

Shaukat SR, Fahim UK, Ibni AK (2014). Genetic variation and heritability estimates of quality traits in Brassica napus L. J. Biol. Agric. Healthcare. 4(20):1-4

Sinhamahapatra SP, Asif BS, Subrata B, Panna M (2003). Multilocular upright siliqua: A promising plant type for increasing seed yield in yellow sarson (Brassica campestris L.). In: Proceedings of Annual Botanical Conference, 29-30 December, Department of Botany, Jahangirnagar University, Dhaka, Bangladesh, P. 15.

Shikari AB, Sinhamahapatra SP (2004). Effect of siliqua angle on seed yield and its component attributes in tera-locular
Brassica campestris (L) var. yellow sarson. Cruciferae Newsletter. (25):57-58.

Yan Z (1990). Overview of rapeseed production and research in China. Proc. Int. Canola Conf., Potash and Phosphate Institute, Atlanta, pp. 29-35.

Varshney SK, Rai B, Singh B (1986). A comparative assessment of harvest index and other economic attributes in three cultivated species of Brassica. J. Oilseeds Res. 3:158-163.

Warwick SI, Al-Shehbaz IA (2006). Brassicaceae: chromosome number index and database on CD-ROM. PI. Syst. Evol. 259:237-248. 